\title{
Accessibility and agglomeration: A theoretical framework for understanding the connection between transportation modes, agglomeration benefits, and types of businesses
}

\section{Kevin Credit (D)}

Center for Spatial Data Science, University of Chicago

\section{Correspondence}

Kevin Credit, Lecturer in GIScience, Assistant Director for Urban Informatics, Center for Spatial Data Science, University of Chicago, Chicago, Illinois.

Email: kcredit@uchicago.edu

Funding information

Michigan State University, Grant/Award Number: Dissertation Completion Fellowship

\begin{abstract}
While delineating the connection between transportation accessibility and economic activity has long been a topic of interest in geography and regional science, a better understanding of the agglomerative benefits of transportation systems is vital. This paper seeks to tie the concepts of accessibility and agglomeration together by arguing that accessibility benefits ultimately stem from the agglomerative potential created by various transportation investments. This line of reasoning provides an avenue to use the economic mechanisms described in agglomeration theory to analyze the effects of specific transportation modes. To do this, the paper traces the literature on the economic impacts of transportation systems and presents a theoretical framework for understanding the connection between specific transportation modes and specific agglomeration benefits. Ultimately, specific modes have unique features that are more or less conducive to specific agglomeration benefits, to which specific types of businesses also respond. These specific connections are particularly important to understand as the development of new urban transportation modes, for example, autonomous vehicles-and their potential economic impacts-increases rapidly.
\end{abstract}




\section{1 | INTRODUCTION}

The economic impact of transportation systems-and the dynamic interplay between urban development, economic development, and transportation accessibility-has long been studied in economic geography, regional science, and urban planning (Alonso, 1960, 1964; von Thünen, 1826). Recent research on the economic effects of transportation systems has raised interesting theoretical questions regarding the extent to which roads and public transit systems foster agglomeration benefits to businesses, both locally and regionally (Chatman \& Noland, 2011; Credit, 2018; Gerritse \& Arribas-Bel, 2018; Holl, 2006; Yu, Junfeng, Houston, \& Peng, 2018).

Traditionally, the theoretical concepts of agglomeration economies-the benefits that businesses obtain by locating close to one another (Glaeser, 2010) and the economic benefits of accessibility, a given location's physical connection to "spatially distributed activities (for employment, recreation, social interaction, etc.)" (Martellato \& Nijkamp, 1998; Paez, Scott, \& Morency, 2012, p. 141)-have been developed in separate literatures with somewhat different aims. The agglomeration literature often passes over the mechanisms of colocation (which are, arguably, always dependent on transportation systems ${ }^{1}$ ) in favor of delineating and empirically testing a detailed set of economic benefits to businesses. These are typically divided into two broad categories: localization economies are benefits that accrue to businesses within a given industry, such as specialized labor pools, nontraded inputs, and increased information availability (Hoover, 1937; Marshall, 1890), while urbanization economies are benefits that businesses receive from locating in an urban area, such as interindustry knowledge spillovers, higher levels of human capital, and access to larger consumer markets and more specialized support services and institutions (Florida, 2002; Hoover, 1937; Jacobs, 1967).

The economic benefits of accessibility literature, on the other hand, engage explicitly with the role of transportation systems in generating economic potential and often follow the classic bid-rent model in positing that increased accessibility leads to increased property values, which then create an economic incentive for the development of higher-intensity land uses (e.g., commercial and high density residential; Alonso, 1960, 1964; Giuliano, 2004). Thus, as Figure 1 shows, in the accessibility framework, the location choices of individual businesses are often seen as a byproduct of property value increases, theoretically untied to specific characteristics of the businesses themselves or to the transportation mode being introduced.

Although the concepts of agglomeration and accessibility have been previously theoretically distinct, the goal of this paper is to tie these ideas together by arguing that accessibility benefits can be viewed as ultimately stemming from the agglomerative potential created by various transportation investments, because any transportation investment that improves accessibility also has the effect of bringing economic agents into greater proximity. This line of argumentation then provides an avenue to use the more robust, specific economic mechanisms delineated in agglomeration theory to critically analyze the economic effects of specific transportation modes. This is theoretically useful because the traditional accessibility literature often passes over the specific mechanisms through which increased accessibility leads to specific economic benefits for specific types of businesses. It is the sum of these benefits that becomes capitalized in property value increases, which are only one by-product of the value of the agglomeration benefits to individual businesses. These agglomerative mechanisms also produce other benefits both external (such as new business creation and spillover development) and internal (such as productivity and employment increases)

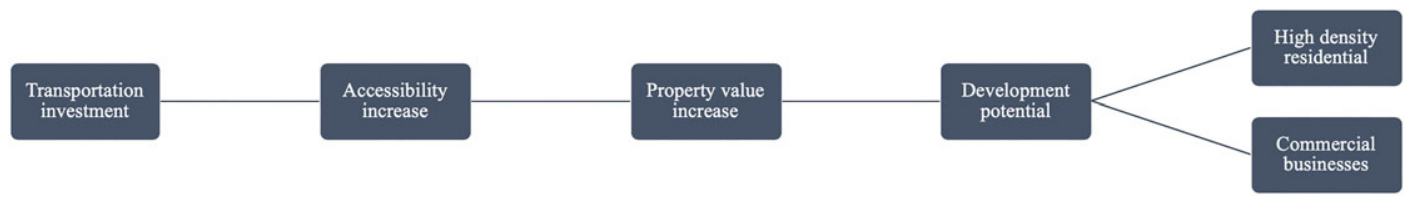

FIGURE 1 Diagram showing theoretical connections between transportation investment, property value increases, and development potential based on classic bid-rent theory 
to the firm. Thus, agglomeration theory provides a useful existing conceptual toolbox for describing and delineating these specific economic mechanisms (explained in more detail in Section 3 below), as shown in Figure 2. In addition, these agglomeration benefits occur at very fine spatial scales, which are now increasingly open to empirical analysis through point-level establishment datasets such as InfoUSA and the National Establishment Time Series (NETS).

By thinking about the economic benefits of transportation systems in this way-in effect "exploding" the theoretical mechanisms through which specific transportation modes contribute to specific economic benefits to specific types of businesses at fine-grained spatial scales-researchers will be able to better study how different kinds of transportation systems influence the location choices of different kinds of businesses. This has the potential to lead to more targeted (and useful) findings for both entrepreneurs and local policy makers. Understanding the fine-grained economic mechanisms at work in the interplay between transportation investment and business location is particularly important as new transportation modes-such as shared autonomous vehicles (SAVs)-are created and as local governments continue to pursue the development of more sustainable transportation systems (Freemark, 2014).

This paper explores this theoretical perspective by first examining the previous literature on the economic effects of transportation systems before developing a theoretical framework for understanding the connections between specific transportation modes, agglomerative mechanisms, and the types of businesses that might theoretically benefit from these mechanisms. The paper closes with a brief discussion of the implications of these connections for future research and policy making.

\section{I ECONOMIC EFFECTS OF TRANSPORTATION SYSTEMS}

For the purposes of this review, it is useful to think of the literature on the economic effects of transportation investments in three parts: (1) von Thünen (1826) and Alonso's $(1960,1964)$ classic bid-rent theory provides the conceptual underpinning for research on the economic effects of transportation systems, which led to (2) empirical work analyzing the impacts of transportation investments on (most often) property values and employment; only very recently

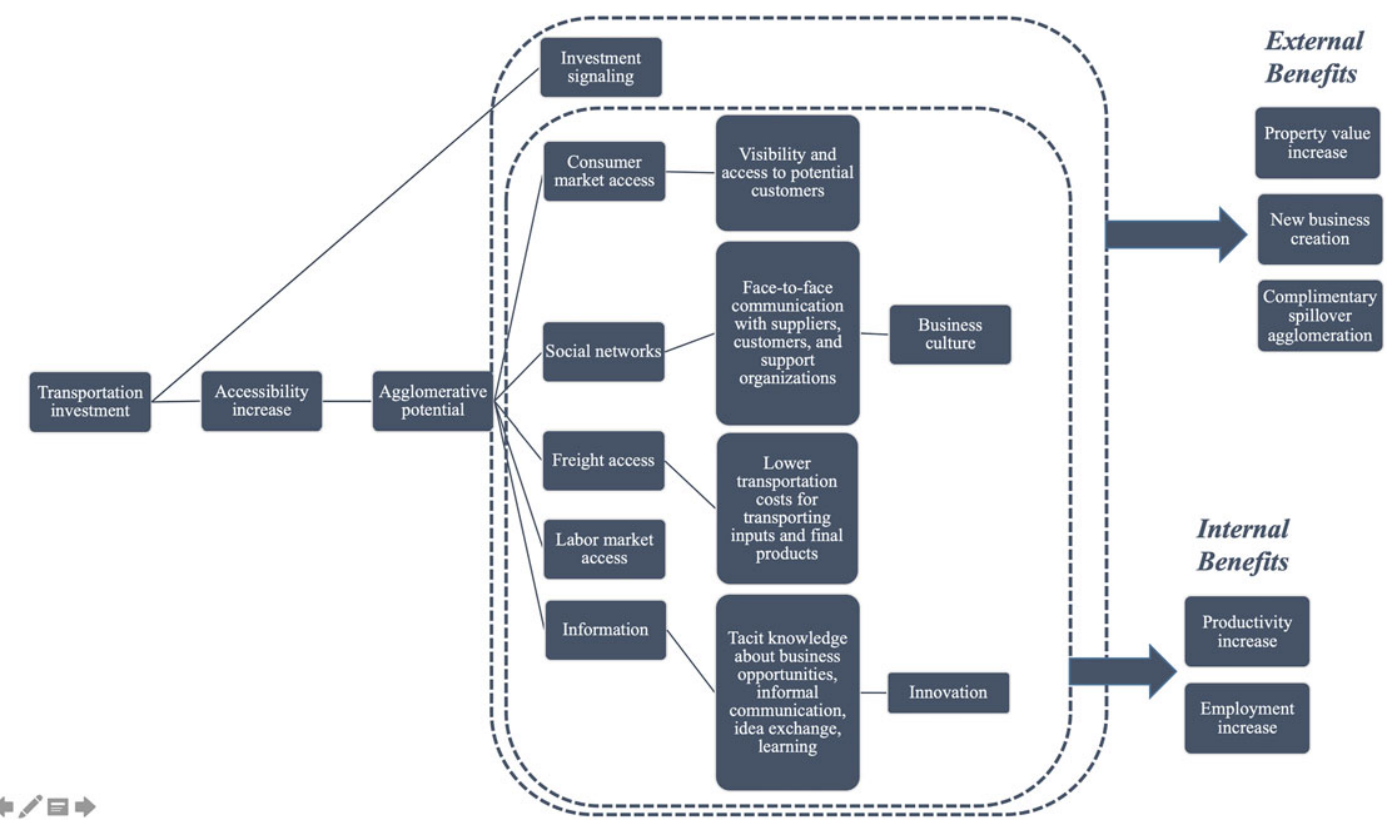

FIGURE 2 Diagram showing proposed theoretical connections between transportation investment, agglomeration benefits, and property value increases 
has localized business agglomeration around transportation investments begun to be examined in the literature in earnest. At the same time, (3) another literature has examined the microfoundations of agglomeration economies in general, focusing on measuring the spatial extent of various agglomeration benefits. While scholars have recently begun to examine the connection between transportation and agglomeration using effective density measures of agglomeration (Graham, 2007a, 2007b; Graham \& Gibbons, 2018; Melo, Graham, Levinson, \& Aarabi, 2017), there is significant room to expand the existing research record by examining the local agglomeration impacts of transportation investments using point-based data on individual establishments. Thus, the goal of this paper is to bridge these literatures by developing a conceptual framework that connects business location decision making to agglomeration mechanisms at the local scale.

Transportation costs play a central role in bid-rent theory, which attempts to explain the distribution and spatial pattern of various economic activities based on purely economic considerations. In von Thünen's (1826) original theory of agricultural land use allocation, transportation cost (per acre product) for various goods determines the concentric distribution of land uses; heavier or bulkier products will be grown closest to the market (such as milk), while lighter products or those that require a large areal extent (like wheat) will be located furthest from the market (Beckmann, 1968).

Alonso (1960, 1964), Muth (1968), and Mills (1967, 1972) extend this concept to urban land uses, positing that uses or residents requiring a shorter commute-such as commercial businesses that depend on face-to-face contact or low-income households with limited transportation budgets-will be willing to bid higher amounts for land located closest to the center, while uses and residents that require more land (and/or can afford a longer commute) will locate further from the center. The spatial distribution of land uses in the city, then, is determined by a gradient of property values based on accessibility to the center (through transportation networks), where higher intensity uses outbid lower intensity uses at the most accessible (and thus most expensive) locations. A diagram of the classic urban bid-rent function is shown in Figure 3. These relationships also manifest themselves in the specific localized impact of real-world transportation networks-given the fact that transportation systems increase accessibility and property values (and thus higher-intently land uses) are expected to be higher near transportation investments (Alonso, 1964; Giuliano, 2004).

Empirical research on the extent to which highway investments increase regional property values began in earnest in the late 1950s and early 1960s (Adkins, 1959; Giuliano, 2004; Mohring, 1961), typically showing significant regional increases in land values as highway accessibility increases. While more recent studies generally confirm the positive property value, employment, and business-clustering effects of highway accessibility (Bollinger \& Ihlanfeldt, 1997; Chandra \& Thompson, 2000; Duranton \& Turner, 2012; Holl, 2004a, 2007; Ryan, 2005; Seo, Golub, \& Kuby, 2014; Voith, 1993), there is also evidence that contextual factors, such as available land for new construction and favorable regional economic conditions, play a significant role in mediating the economic impact of highway investments, with some studies showing insignificant or negative effects (Boarnet \& Chalermpong, 2001; Giuliano, 2004; Giuliano, Gordon, Pan, \& Park, 2010). This trend towards diminishing returns certainly makes sense; as highway networks become more fully built out, the incremental increase in accessibility from each highway project necessarily decreases. Of course, proximity to highways also creates disamenities such as traffic noise and air pollution, which tend to lower residential property values, particularly along highway links (Nelson, 1982).

Similar work on the economic impact of public transit systems began in the 1970s and 1980s (Cervero, 1984; Cervero, 1994; Knight \& Trygg, 1977) and generally supports the idea that station proximity increases property values and thus development intensity, primarily when the service itself is frequent and reliable, when the system is planned in conjunction with supportive land use policies, and is built in areas with high existing economic growth and development potential (Agostini \& Palmucci, 2008; Cervero, 1984; Cervero, 1994; Cervero, 2004; Damm, Lerman, Lerner-Lam, \& Young, 1980; Golub, Guhathakurta, \& Sollapuram, 2012; Hess \& Almeida, 2007; Knaap, Ding, \& Hopkins, 2001; Knight \& Trygg, 1977; Landis, Guhathakurta, \& Zhang, 1994; Seo et al., 2014; Weinberger, 2001; Weinstein \& Clower, 2003). While other researchers have pointed out that the economic benefits observed due to transit systems may be (1) simply a refocusing of development that would have occurred somewhere else (e.g., the 


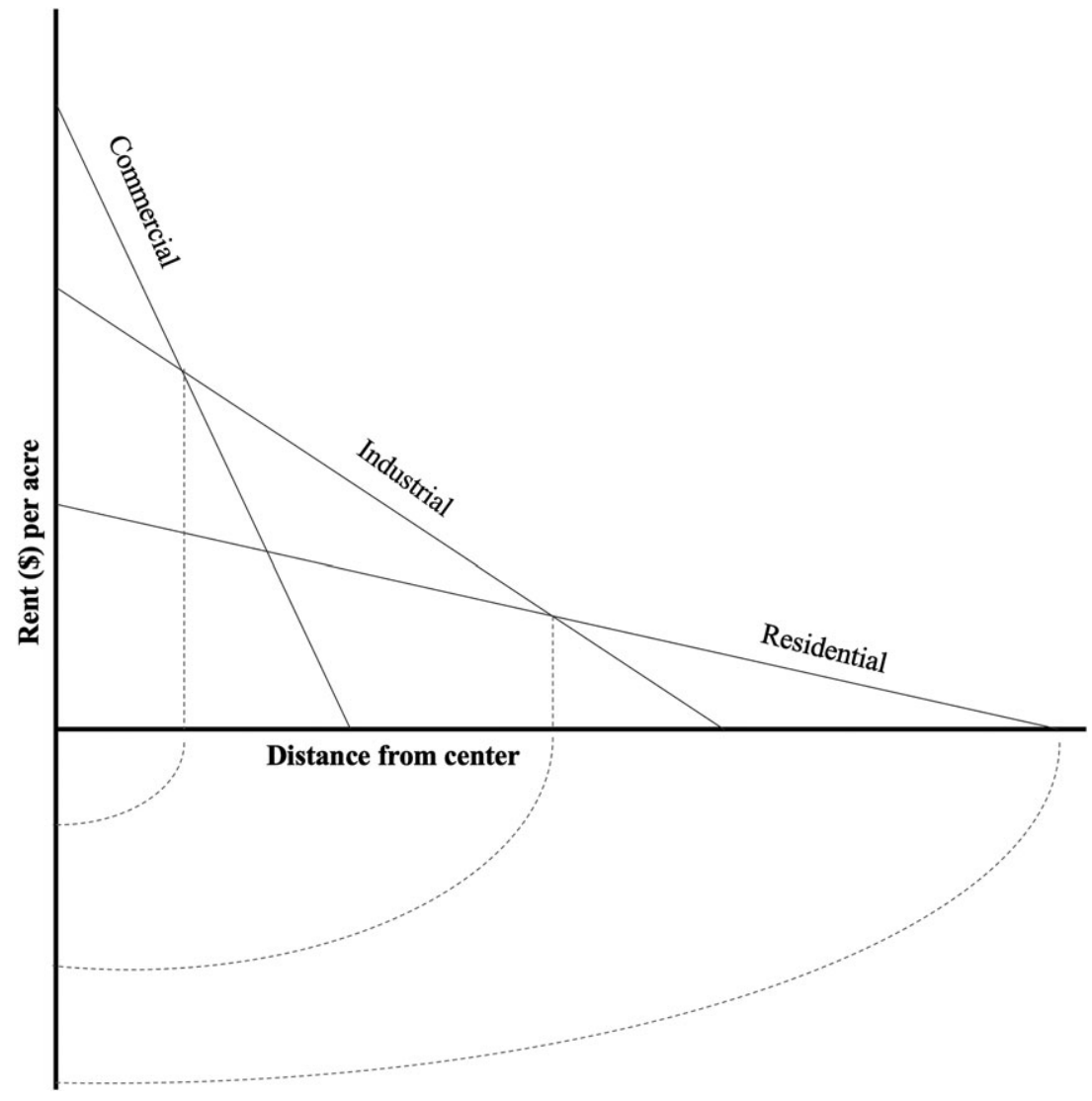

FIGURE 3 Diagram showing hierarchy of different transportation mode types

suburbs) or (2) predominantly due to regional economic conditions (Giuliano, 2004; Schuetz, 2014; Vessali, 1996), a recent meta-analysis has confirmed that, overall, transit generally confers property value benefits to adjacent areas (Mohammad, Graham, Melo, \& Anderson, 2013).

Research that evaluates the localized association between transportation systems and new business creation also generally confirms the positive role of transportation investments on business agglomeration (Chatman, Noland, \& Klein, 2016; Credit, 2018; Holl, 2004a, 2004b; Mejia-Dorantes, Paez, \& Vassallo, 2012; Song, Lee, Anderson, \& Lakshmanan, 2012). However, given the small number of studies directly evaluating business agglomeration around transportation investments, additional work in this area is certainly needed.

While some have begun to study the local agglomeration impacts of transportation systems on business productivity using effective density measures, which operationalize agglomeration as the total amount of economic activity accessible within some travel radius of a given spatial unit based on the characteristics of the road network (Graham, 2007a, 2007b; Graham \& Gibbons, 2018; Melo et al., 2017), much of the research that explicitly addresses the agglomeration benefits of transportation systems still operationalizes agglomeration at the city or regional scale (Chatman \& Noland, 2011; Gerritse \& Arribas-Bel, 2018). However, researchers in the agglomeration literature at large have shown that agglomeration impacts often occur at very small scales, calling attention to the need to study these processes more closely (Andersson, Klaesson, \& Larsson, 2014; Arauzo-Carod \& ViladecansMarsal, 2009; Garcia-López \& Muñiz, 2011; Kerr \& Kominers, 2015; Rosenthal \& Strange, 2003; Van Soest, Gerking, \& Van Oort, 2006).

Given this gap in the existing literature, the purpose of this paper is to theoretically tie these microagglomeration mechanisms more closely to the economic effects of transportation literature by developing a theoretical framework 
that links specific transportation modes to specific agglomeration mechanisms and-through these mechanisms-to specific types of businesses.

\section{I FRAMEWORK FOR UNDERSTANDING THE AGGLOMERATION BENEFITS OF SPECIFIC TRANSPORTATION MODES}

As this discussion demonstrates, while the literature that examines the economic effects of transportation systems is quite large, much of the existing work focuses property value premiums rather than business agglomeration as the economic outcome of interest (Cervero \& Landis, 1997; Golub et al., 2012; Knaap et al., 2001; Seo et al., 2014). At the same time, work explicitly appraising the agglomeration benefits of transportation systems too often conceptualizes them at the regional scale (Chatman \& Noland, 2011; Gerritse \& Arribas-Bel, 2018), despite the fact that agglomeration mechanisms have been shown to operate over relatively short distances (Andersson et al., 2014; Arauzo-Carod \& Viladecans-Marsal, 2009; Garcia-López \& Muñiz, 2011; Graham, 2007a, 2007b; Graham \& Gibbons, 2018; Kerr \& Kominers, 2015; Melo et al., 2017; Rosenthal \& Strange, 2003; Van Soest et al., 2006).

While property value increases are important indicators of economic value and directly relevant to municipal governments interested in raising property tax revenues, it stands to reason that property value increases are in fact an economic by-product of the true mechanism through which transportation increases economic growth: agglomeration economies (Hoover, 1937; Jacobs, 1967; Marshall, 1890). While all transportation systems create some level of agglomerative potential, different modes have unique features that are more or less conducive to specific agglomeration benefits, and different kinds of businesses also respond differently to various agglomeration benefits (Chatman \& Noland, 2011).

Figure 2 shows the theorized agglomeration mechanisms through which transportation investments create various economic benefits both internal and external to the firm, including property values. The direct impact of a new transportation investment is an increase in accessibility for parcels of land adjacent to it (Alonso, 1960, 1964; Giuliano, 2004). Immediately, that land becomes more connected to the rest of the region and to other regions, and the cost of moving goods, services, people, and information decreases. Of course, the degree or type of accessibility increase is determined by a multitude of factors specific to the mode; for example, transit stations must be supplemented by well-designed pedestrian environments in order to reach their full potential for use (Newman \& Kenworthy, 2013). These nuances of accessibility are one important factor in determining how different kinds of transportation investments impact different kinds of business development. ${ }^{2}$

The other important factor is the nature of the specific agglomeration mechanisms provided by the increase in accessibility. As Figure 2 shows, we can think of six primary agglomeration benefits facilitated through accessibility increases: consumer market access, social networks, freight access, labor market access, information, and the potential for complimentary spillover development (Chatman \& Noland, 2011; Gordon \& McCann, 2000; Helsley \& Zenou, 2014; Hoover, 1937; Jacobs, 1967; Marshall, 1890; McCann \& Sheppard, 2003; Porter, 2000).

It is important to note that the accessibility increases only create an agglomerative potential in surrounding land parcels by better connecting them to other parts of the region (or other regions); additional factors like specific site, situation, distance to the central business district (CBD), land use regulations and plans, specific nature of the business, and many other factors will of course also influence the degree to which agglomeration benefits actually accrue to a piece of land. The specific factors of the site, region, and business will also influence whether the benefits are primarily classified as localization or urbanization economies-while the six factors identified here could certainly all be classified as urbanization benefits, they also have the potential to increase localization benefits as well (e.g., by better connecting specialized industrial suppliers with producers in the region and decreasing input costs).

In any case, accessibility increases from transportation investments have the potential to increase the visibility of a business, which is especially important to retail and service firms who rely on walk-in or pass-through traffic, as well as access to customers generally by better connecting the parcel to the entire urban market (or other markets). 
Transportation also fosters social network creation and the maintenance of "weak ties" by lowering the cost of faceto-face communication (Gordon \& McCann, 2000; Helsley \& Zenou, 2014; McCann \& Sheppard, 2003; Storper \& Scott, 2009; Storper \& Venables, 2004). This is particularly important for economic development, because the social connections between producers, suppliers, customers, and support organizations have been shown to be a key component for fostering new business creation and the development of entrepreneurial ecosystems (Mack \& Mayer, 2015; Spigel, 2015), as well as for developing a unique culture conducive of competition and cooperation that increases regional competitiveness (Porter, 2000; Saxenian, 1994). The movement of factor inputs and outputs is also facilitated by accessibility increases, which lowers the cost of production. Similarly, labor market access for a parcel is increased by new transportation investment, lowering the cost of finding new employees.

One of the most critical benefits created by accessibility increases is an increase in information availability (Hoover, 1937; Marshall, 1890). This benefits businesses not only by providing easier access to knowledge of new business opportunities or competitive strategies (Figueiredo, Guimaraes, \& Woodward, 2002; Stam, 2007) but also by fostering informal interactions and idea exchange-even among employees in different industries-that can lead to regional learning, innovation, and eventually entrepreneurship (Jacobs, 1967; Saxenian, 1994; Wennekers \& Thurik, 1999). These impacts to entrepreneurship-which are also supported by the presence of the other agglomerative benefits identified here-are critically important for creating sustainable regional economies, because new businesses drive technological change, create employment, and protect the region from macroscale economic shocks (Birch, 1987; Jacobs, 1967; Wennekers \& Thurik, 1999).

As Figure 2 also shows, the economic potential created by a transportation investment is substantial in range. The result of the presence of these agglomeration factors can be quantified in a variety of ways and classified as either internal or external to the firm. While property value increases are an important (and oft-researched) external indicator of increased accessibility, there are additional external benefits from agglomeration, including new business creation (the focus of the next section of the paper) and complimentary spillover agglomeration. This kind of complimentary agglomeration is generated as increased accessibility in one location creates spillover effects for neighboring parcels of land. For instance, a new transit station not only increases the agglomerative potential of the parcels immediately adjacent to it, likely leading to some new business creation or relocation there, it also creates secondary benefits on nearby parcels; if those develop into complimentary businesses, additional localization or urbanization economies could be created based on the burgeoning cluster of new business activity focused on the transit station.

While the focus of this article is on the external benefits delineated above, benefits internal to firms are also very important to consider (Graham, 2007a, 2007b; Melo et al., 2017). For instance, highway access has been shown to positively impact the productivity of manufacturing and logistics businesses (Baird, 2005; Holl, 2016; Holl \& Mariotti, 2018). The agglomeration mechanisms delineated here also have the potential to foster an increase in an individual firm's employment levels as it becomes more competitive. Of course, agglomeration benefits internal to the firm are also in no way mutually exclusive to those external; for example, a new transit station could help an adjacent existing technology firm increase its productivity and employment by helping it to acquire additional tacit knowledge about business opportunities while at the same time providing a host of potential external agglomeration benefits that attract new firms and complimentary spillover agglomeration (e.g., a new coffee shop opens to serve the new employees of the technology firm, etc.).

Finally, there may be additional economic benefits from transportation investments that are not related to a perceptible increase in accessibility. Specifically, Fischer (2018) has identified the important role of public transit infrastructure in signaling to entrepreneurs that the local government is committed to investing in specific neighborhoods, which fosters adjacent new business creation, complimentary spillover development, and increased property values. In the case of the Kansas City Streetcar, these signaling benefits are potentially larger than any benefits that emerge from true accessibility increases. While these benefits technically fall outside of the accessibilityagglomeration paradigm outlined here, this type of mechanism represents an interesting and understudied alternative pathway through which transportation investments might foster external economic benefits and certainly deserves additional empirical research. 


\section{I CONNECTIONS BETWEEN ACCESSIBILITY BENEFITS OF SPECIFIC MODES, AGGLOMERATION BENEFITS, AND SPECIFIC TYPES OF BUSINESSES}

In addition to the lack of research into the specific mechanisms through which transportation systems create agglomerative potential, there is likewise a lack of work on the economic connection between urban transportation modes and specific types of businesses, that is, what industries gain most from what kinds of transportation investments. Transportation modes can be broken down (for economic purposes) in several ways based on their cargo type and speed. As Figure 3 shows, at the most basic level, a given transportation mode can carry either humans or freight. Passenger modes can also be classified by their speed-"rapid" modes like automobiles and transit have higher mobility and are generally able to connect larger portions of the region, while "slow" modes like biking and walking allow users to interact with their environment at a slower speed and a human scale, allowing for chance encounters, increased physical activity, and enjoyment (Vojnovic et al., 2013). In addition, rideshare, transit, and walking do not require users to own or operate a vehicle, which (beyond financial savings) increases their freedom to engage in social activities-both formal and informal-that may involve drinking.

While it is perhaps debatable whether existing rideshare services such as Uber/Uber Pool and future shared autonomous vehicle (SAV) networks constitute a distinct mode from the automobile (or transit), they are separated here precisely to call attention to their unique features and to ponder whether different kinds of agglomeration benefits might be expected to result from their use (Fagnant \& Kockelman, 2014). These services share some attributes with traditional transit or microtransit modes and some with traditional single-occupancy automobiles. From a user standpoint, rideshare and SAVs behave like technology-assisted, on-demand transit systems (albeit with very low vehicle capacities)-users do not own a vehicle and there is the potential for some spontaneous and informal face-to-face interaction, both within the vehicle (in the case of a pooled rideshare) and in the ability to engage in social networking events, for example, happy hours. However, the characteristics of the infrastructure investment itself are essentially identical to the automobile; even if a fully connected autonomous vehicle network required new infrastructure to be built, its economically relevant transportation characteristics (i.e., nodes and links) would not differ significantly from the automobile. Thus, for the purposes of this paper, the appropriate categorization for these modes appears to be within both "rapid" and "no vehicle," as shown in Figure 4.

Connections (shown in Table 1) can then be made from these broad classes of transportation modes to each of the agglomeration benefits outlined above, which are themselves connected to specific types of businesses, which might theoretically be predisposed to benefit from specific types of agglomeration benefits. Consumer market area benefits are most likely to be created by rapid transit modes, since these extend regionally rather than at a neighborhood scale (Rosenthal \& Strange, 2003); the businesses most likely to benefit from these economies are customer-oriented firms like retailers, services, entertainment, and healthcare. These are businesses for which access is very important; thus, well-planned automobile and transit infrastructure investments are most likely to benefit or encourage these types of businesses. As might be expected, freight access is only theoretically benefited by modes that carry cargo, which serves firms in sectors like manufacturing, wholesale, and large-scale retail most prominently. Labor market access requires regional-scale access to people (Rosenthal \& Strange, 2003) but is likely most useful for businesses without specialized hiring needs, such as manufacturing, wholesale, retail, personal services, food, and entertainment. Industries that are more specialized or require higher levels of human capital will most likely conduct targeted searches for employees that are less dependent on transportation access to a large pool of candidates.

Social networks are fostered through all kinds of interpersonal interaction, sometimes extending regionally (as in the case of clients for advanced service firms or business network organizations) as well as locally (Nelson, 2005). The businesses most likely to benefit from this kind of face-to-face communication are those require a lot of face-to-face communication and interaction to do business: advanced service firms (e.g., consultants), high-tech businesses, and educational institutions. However, while all passenger modes increase interpersonal 


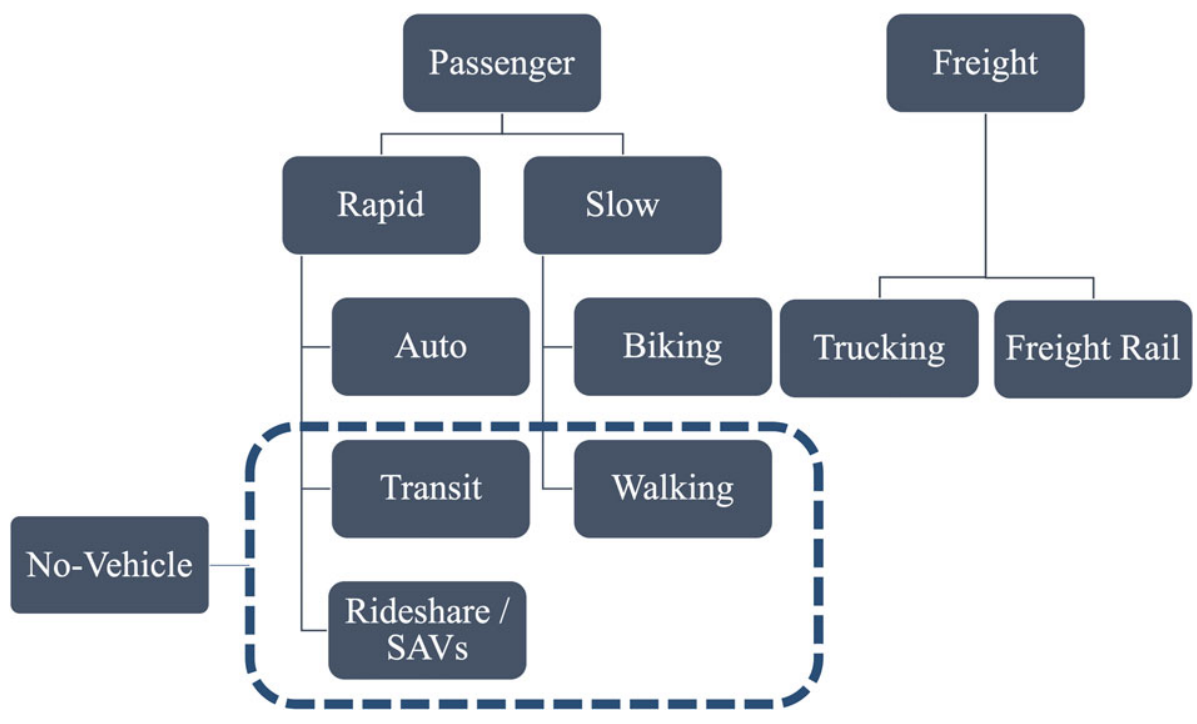

FIGURE 4 Diagram showing hierarchy of different transportation mode types

TABLE 1 Theorized tendencies for transportation modes to produce given agglomerative economies, and the business types most likely to benefit

\begin{tabular}{|c|c|c|}
\hline $\begin{array}{l}\text { Transportation } \\
\text { mode }\end{array}$ & $\begin{array}{l}\text { Agglomeration } \\
\text { mechanism }\end{array}$ & Business types \\
\hline Rapid & $\begin{array}{l}\text { Consumer market } \\
\text { access }\end{array}$ & $\begin{array}{l}\text { Large- and small-scale retail, personal services, food, entertainment, } \\
\text { healthcare }\end{array}$ \\
\hline All passenger & Social networks & Advanced services, high-tech, education \\
\hline Freight & Freight access & Manufacturing, wholesale, large-scale retail \\
\hline Rapid & Labor market access & $\begin{array}{l}\text { Manufacturing, wholesale, large- and small-scale retail, personal services, } \\
\text { food, and entertainment }\end{array}$ \\
\hline Slow & Information & Advanced services, high-tech, education \\
\hline No vehicle & $\begin{array}{c}\text { Social networks, } \\
\text { information }\end{array}$ & Advanced services, high-tech, education \\
\hline
\end{tabular}

accessibility and the opportunity to build social networks to some extent, research has shown that the kinds of informal interactions and network building that are particularly relevant to knowledge spillovers and entrepreneurship often occur at happy hours and other types of networking events where drinking is involved: Saxenian (1994) and Wolfe (1983) describe in vivid detail the knowledge spillovers that occurred between Silicon Valley firms at the Wagon Wheel Bar, described as the "fountainhead of the semiconductor industry." Certainly, transportation modes that do not require the use/ownership of a personal vehicle are particularly impactful for fostering these situations.

These types of information economies are likewise fostered by "slow" transportation modes that favor chance encounters, informal interaction, casual socialization, reflection, and personal experience of situations and conditions. Previous research on information benefits has shown that they are present only over relatively short distances (Rosenthal \& Strange, 2003; Van Soest et al., 2006), which makes sense due to the fact that they are related to personal exchanges and knowledge of local conditions. And, while information economies can benefit businesses in all sectors, they are particularly useful for businesses in advanced services, high-tech, and education. 


\section{5 | DISCUSSION AND CONCLUSION}

Of course, additional empirical research-currently lacking in the literature-is needed to confirm, complicate, or reject the broad connections sketched out here, specifically when it comes to the "no-vehicle" and "slow" transportation modes. There are also additional modal distinctions-within transit, for example, between light rail, heavy rail, and commuter rail modes-that could to be examined in more detail, given the vast differences in cost, user perception, and political palatability between them. Regional comparisons are also needed between areas with historically dense urban development patterns and well-developed, mature transit systems (like Chicago or Boston) and those focused currently on auto-oriented development and highway construction (such as Phoenix or Los Angeles). Different regions also of course have vastly different industrial concentrations, business cultures, internal supply/demand structures, and patterns of investment that will influence the connection between any individual business and a given transportation mode. In addition, fine-grained temporal considerations, such as the "novelty factor" identified by previous researchers that suggests a new transportation investment is most economically important at the time it opens, with declining importance as it continues to operate and the novelty wears off (Golub et al., 2012; Mohammad et al., 2013), need to be considered in more detail.

Existing empirical research has only just begun to broach these subjects in a meaningful way. The existing work on the connection between transportation and agglomeration does not sufficiently explore the fine-grained, individual mechanisms through which specific transportation modes increase agglomerative potential (Chatman \& Noland, 2011). And while researchers have begun to study the connection between public transit modes and new business creation in specific industries and regions (Chatman et al., 2016; Credit, 2018; Mejia-Dorantes et al., 2012; Song et al., 2012), additional study areas, business types, regions, temporal variation, and methodological approaches are needed. With the increasing availability of point-based establishment datasets such as InfoUSA and NETS, researchers are able to begin to examine the theorized connections between transportation modes and business types laid out in this paper.

Additional empirical scrutiny on this topic has the potential to benefit local governments and entrepreneurs alike; transportation planners and policy makers considering the development of new infrastructure investment would be able to better estimate their economic impacts to businesses. This could be particularly useful in the planning process where specific types of surrounding land uses and businesses might be desired to increase urban vitality and activity on the street. At the same time, business owners and entrepreneurs in specific industries could use this information to better understand their location and investment decisions, allowing them to target specific types of infrastructure investment with better knowledge of its specific economic (agglomeration) benefits. Oftentimes, this knowledge is tacitly but informally understood by entrepreneurs; formalizing and extending it would prove a competitive advantage to individual businesses that could benefit regional economies.

\section{ENDNOTES}

${ }^{1}$ Traditionally, agglomeration is conceptualized as the concentration of business or economic activity in a specific area and often operationalized by density measures at the local, municipal, or regional scale. The argument that this paper makes is that "concentration" and "density" ultimately reflect increased proximity between economic agents and that all physical proximity occurs somehow through transportation connections (even businesses on the same block are connected by streets). In other words, referring to the specific transportation links that increase proximity is a more precise way of defining agglomerative connections than has been done previously. And, with this micro-level view of agglomerative proximity, more explicit connections between transportation modes and agglomerative benefits can be distinguished.

${ }^{2}$ It is also important to note that this framework does not take into account diseconomies of agglomeration for these various transportation investments, which must also be considered. For instance, numerous studies have elucidated the nuisance effect for rail transit property values directly adjacent to tracks and/or stations (Mohammad et al., 2013). In this way, this diagram presents only the "positive" side of the photograph. In fact, a similar framework could be made in which specific negative externalities are assigned to specific transportation modes (the "negative" of the same photograph). In the same way that various agglomeration benefits are created by different modes for specific types of businesses, diseconomies of agglomeration also accrue along specific lines. 


\section{ORCID}

Kevin Credit (i) https://orcid.org/0000-0002-3320-4670

\section{REFERENCES}

Adkins, W. G. (1959). Land value impacts of expressways in Dallas, Houston, and San Antonio, Texas. Bulletin 227 (pp. 50-65). Washington, D.C: Highway Research Board.

Agostini, C. A., \& Palmucci, G. (2008). The anticipated capitalization effect of a new metro line on housing prices. Fiscal Studies, 29, 233-256. https://doi.org/10.1111/j.1475-5890.2008.00074.x

Alonso, W. (1960). A theory of the urban land market. Papers in Regional Science, 6(1), 149-157.

Alonso, W. (1964). Location and land use. Cambridge, MA: Harvard University Press. https://doi.org/10.4159/harvard. 9780674730854

Andersson, M., Klaesson, J., \& Larsson, J. P. (2014). How local are spatial density externalities? Neighbourhood effects in agglomeration economies. Regional Studies, 50(6), 1082-1095.

Arauzo-Carod, J. M., \& Viladecans-Marsal, E. (2009). Industrial location at the intra-metropolitan level: The role of agglomeration economies. Regional Studies, 43(4), 545-558. https://doi.org/10.1080/00343400701874172

Baird, B. A. (2005). Public infrastructure and economic productivity: A transportation-focused review. Transportation Research Record, 1932, 54-60.

Beckmann, M. (1968). Location theory. New York, NY: Random House.

Birch, D. (1987). Job creation in America: How our smallest companies put the most people to work. New York, NY: The Free Press.

Boarnet, M. G., \& Chalermpong, S. (2001). New highways, house prices, and urban development: A case study of toll roads in orange county, CA. Housing Policy Debate, 13(3), 575-605.

Bollinger, C. R., \& Ihlanfeldt, K. R. (1997). The impact of rapid rail transit on economic development: The case of Atlanta's MARTA. Journal of Urban Economics, 42, 179-204. https://doi.org/10.1006/juec.1996.2020

Cervero, R. (1984). Light rail transit and urban development. Journal of the American Planning Association, 50(2), 133-147. https://doi.org/10.1080/01944368408977170

Cervero, R. (1994). Rail transit and joint development: Land market impacts in Washington, D.C. and Atlanta. Journal of the American Planning Association, 60(1), 83-94. https://doi.org/10.1080/01944369408975554

Cervero, R. (2004). Effects of light and commuter rail transit on land prices: Experiences in San Diego County. Journal of the Transportation Research Forum, 43(1), 121-138.

Cervero, R., \& Landis, J. (1997). Twenty years of the bay area rapid transit system: Land use and development impacts. Transportation Research Part A, 41(4), 309-333.

Chandra, A., \& Thompson, E. (2000). Does public infrastructure affect economic activity? Evidence from the rural interstate highway system. Regional Science and Urban Economics, 30, 457-490. https://doi.org/10.1016/S0166-0462(00)00040-5

Chatman, D. G., \& Noland, R. B. (2011). Do public transport improvements increase agglomeration economies? A Review of Literature and an Agenda for Research. Transport Reviews, 31(6), 725-742. https://doi.org/10.1080/01441647.2011. 587908

Chatman, D. G., Noland, R. B., \& Klein, N. J. (2016). Firm births, access to transit, and agglomeration in Portland, Oregon, and Dallas, Texas. Transportation Research Record, 2598, 1-10. https://doi.org/10.3141/2598-01

Credit, K. (2018). Transit-oriented economic development: The impact of light rail on new business starts in the Phoenix, AZ Region. Urban Studies, 55(13), 2838-2862. https://doi.org/10.1177/0042098017724119

Damm, D., Lerman, S. R., Lerner-Lam, E., \& Young, J. (1980). Response of urban real estate values in anticipation of the Washington Metro. Journal of Transport Economics and Policy, 14(3), 315-336.

Duranton, G., \& Turner, M. A. (2012). Urban growth and transportation. The Review of Economic Studies, 79(4), 1407-1440. https://doi.org/10.1093/restud/rds010

Fagnant, D. J., \& Kockelman, K. M. (2014). The travel and environmental implications of shared autonomous vehicles, using agent-based model scenarios. Transportation Research Part C, 40, 1-13. https://doi.org/10.1016/j.trc.2013.12.001

Figueiredo, O., Guimaraes, P., \& Woodward, D. (2002). Home-field advantage: Location decisions of Portuguese entrepreneurs. Journal of Urban Economics, 52(2), 341-361. https://doi.org/10.1016/S0094-1190(02)00006-2

Fischer, L.A. (2018). Financing Modern Streetcars: Assessing the Planning Impacts of Value Capture Implementation in Kansas City, MO. Conference Presentation: Annual Meeting of the Association of Collegiate Schools of Planning (ACSP). October 27. 
Florida, R. (2002). The rise of the creative class: And how it's transforming work, leisure, community, and everyday life. New York, NY: Basic Books.

Freemark, Y. (2014). Have U.S. Light Rail Systems Been Worth the Investment? Citylab. Retrieved from: http://www.citylab. com/commute/2014/04/have-us-light-rail-systems-been-worth-investment/8838/.

Garcia-López, M. À., \& Muñiz, I. (2011). Urban spatial structure, agglomeration economies, and economic growth in Barcelona: An intra-metropolitan perspective. Papers in Regional Science, 92(3), 515-534.

Gerritse, M., \& Arribas-Bel, D. (2018). Concrete agglomeration benefits: Do roads improve urban connections or just attract more people? Regional Studies, 52(8), 1134-1149. https://doi.org/10.1080/00343404.2017.1369023

Giuliano, G. (2004). Land Use Impacts of Transportation Investments: Highway and Transit. In S. Hanson, \& G. Giuliano (Eds.), The geography of urban transportation. New York, NY: Guilford Press.

Giuliano, G., Gordon, P., Pan, Q., \& Park, J. (2010). Accessibility and residential land values: Some tests with new measures. Urban Studies, 47(14), 3103-3130. https://doi.org/10.1177/0042098009359949

Glaeser, E. L. (2010). Introduction. In E. L. Glaeser (Ed.), Agglomeration economies. Chicago, IL: University of Chicago Press. https://doi.org/10.7208/chicago/9780226297927.003.0001

Golub, A., Guhathakurta, S., \& Sollapuram, B. (2012). Spatial and temporal capitalization effects of light rail in Phoenix: From conception, planning, and construction to operation. Journal of Planning Education and Research, 32(4), 415-429. https:// doi.org/10.1177/0739456X12455523

Gordon, I. R., \& McCann, P. (2000). Industrial clusters: Complexes, agglomeration and/or social networks? Urban Studies, 37(3), 513-532. https://doi.org/10.1080/0042098002096

Graham, D. J. (2007a). Agglomeration, productivity, and transport investment. Journal of Transport Economics and Policy, 41(3), 317-343.

Graham, D. J. (2007b). Variable returns to agglomeration and the effect of road traffic congestion. Journal of Urban Economics, 62, 103-120. https://doi.org/10.1016/j.jue.2006.10.001

Graham, D.J., and Gibbons, S. (2018). Quantifying Wider Economic Impacts of Agglomeration for Transport Appraisal: Existing Evidence and Future Directions. Centre for Economic Performance (CEP) Discussion Papers, 1561.

Helsley, R. W., \& Zenou, Y. (2014). Social networks and interactions in cities. Journal of Economic Theory, 150, 426-466. https://doi.org/10.1016/j.jet.2013.09.009

Hess, D. B., \& Almeida, T. M. (2007). Impact of proximity to light rail rapid transit on station-area property values in Buffalo, New York. Urban Studies, 44(5-6), 1041-1068. https://doi.org/10.1080/00420980701256005

Holl, A. (2004a). Manufacturing location and impacts of road transport infrastructure: Empirical evidence from Spain. Regional Science and Urban Economics, 34, 341-363. https://doi.org/10.1016/S0166-0462(03)00059-0

Holl, A. (2004b). Transport infrastructure, agglomeration economies, and firm birth: Empirical evidence from Portugal. Journal of Regional Science, 44(4), 698-712.

Holl, A. (2006). A review of the firm-level role of transport infrastructure with implications for transport project evaluation. Journal of Planning Literature, 21(1), 3-13. https://doi.org/10.1177/0885412206288905

Holl, A. (2007). Twenty years of accessibility improvements. The case of the Spanish motorway building programme. Journal of Transport Geography, 15, 286-297. https://doi.org/10.1016/j.jtrangeo.2006.09.003

Holl, A. (2016). Highways and productivity in manufacturing firms. Journal of Urban Economics, 93, 131-151. https://doi.org/ 10.1016/j.jue.2016.04.002

Holl, A., \& Mariotti, I. (2018). Highways and firm performance in the logistics industry. Journal of Transport Geography, 72 , 139-150. https://doi.org/10.1016/j.jtrangeo.2018.08.021

Hoover, E. M. (1937). Location theory and the shoe and leather industries. Cambridge, MA: Harvard University Press. https:// doi.org/10.4159/harvard.9780674498624

Jacobs, J. (1967). The economy of cities. New York, NY: Random House.

Kerr, W. R., \& Kominers, S. D. (2015). Agglomerative forces and cluster shapes. The Review of Economics and Statistics, 97(4), 877-899. https://doi.org/10.1162/REST_a_00471

Knaap, G., Ding, J. C., \& Hopkins, L. D. (2001). Do plans matter? The effects of light rail plans on land values in station areas. Journal of Planning Education and Research, 21(1), 32-39. https://doi.org/10.1177/0739456X0102100103

Knight, R. L., \& Trygg, L. L. (1977). Evidence of land use impacts of rapid transit systems. Transportation, 6(3), $231-247$.

Landis, J., Guhathakurta, S., \& Zhang, M. (1994). Capitalization of transit investments into single-family home prices: A comparative analysis of five California rail transit systems. The University Of California Transportation Center, 246, 1-38. Retrieved from: http://www.uctc.net/papers/246.pdf 
Mack, E., \& Mayer, H. (2015). The evolutionary dynamics of entrepreneurial ecosystems. Urban Studies, 53, 2118-2133. https://doi.org/10.1177/0042098015586547

Marshall, A. (1890). Principles of economics. London, UK: Macmillan.

Martellato, D., \& Nijkamp, P. (1998). The Concept of Accessibility Revisited. In A. Reggiani (Ed.), Accessibility, Trade and Locational Behaviour (pp. 17-40). Aldershot: Ashgate.

McCann, P., \& Sheppard, S. (2003). The rise, fall, and rise again of industrial location theory. Regional Studies, 37(6-7), 649-663. https://doi.org/10.1080/0034340032000108741

Mejia-Dorantes, L., Paez, A., \& Vassallo, J. M. (2012). Transportation infrastructure impacts on firm location: The effect of a new metro line in the suburbs of Madrid. Journal of Transport Geography, 22, 236-250. https://doi.org/10.1016/j. jtrangeo.2011.09.006

Melo, P. C., Graham, D. J., Levinson, D., \& Aarabi, S. (2017). Agglomeration, accessibility, and productivity: Evidence for large metropolitan areas in the US. Urban Studies, 54(1), 179-195. https://doi.org/10.1177/0042098015624850

Mills, E. S. (1967). An aggregative model of resource allocation in a metropolitan area. American Economic Review, 57, 197-210.

Mills, E. S. (1972). Studies in the structure of the urban economy. Baltimore, MD: The Johns Hopkins Press.

Mohammad, S. I., Graham, D. J., Melo, P. C., \& Anderson, R. J. (2013). A meta-analysis of the impact of rail projects on land and property values. Transportation Research Part A, 50, 158-170.

Mohring, H. (1961). Land values and the measurement of highway benefits. Journal of Political Economy, 69(236), 236-249. https://doi.org/10.1086/258466

Muth, R. (1968). Cities and housing. Chicago, IL: University of Chicago Press.

Nelson, J. P. (1982). Highway noise and property values: A survey of recent evidence. Journal of Transport Economics and Policy, 16(2), 117-138.

Nelson, M. (2005). Rethinking agglomeration economies and the role of the central city. Journal of Planning Education and Research, 24(3), 331-341. https://doi.org/10.1177/0739456X04270128

Newman, P., \& Kenworthy, J. (2013). Urban sustainability and automobile dependence in an Australian context. In I. Vojnovic (Ed.), Urban sustainability: A global perspective (pp. 227-253). East Lansing, MI: Michigan State University Press.

Paez, A., Scott, D. M., \& Morency, C. (2012). Measuring accessibility: Positive and normative implementations of various accessibility indicators. Journal of Transport Geography, 25, 141-153. https://doi.org/10.1016/j.jtrangeo.2012.03.016

Porter, M. (2000). Location, competition, and economic development: Local clusters in a global economy. Economic Development Quarterly, 14(1), 15-34. https://doi.org/10.1177/089124240001400105

Rosenthal, S. S., \& Strange, W. C. (2003). Geography, industrial organization, and agglomeration. The Review of Economics and Statistics, 85(2), 377-393. https://doi.org/10.1162/003465303765299882

Ryan, S. (2005). The value of access to highways and light rail transit: Evidence for industrial and office firms. Urban Studies, 42(4), 751-764. https://doi.org/10.1080/00420980500060350

Saxenian, A. (1994). Regional advantage: Culture and competition in Silicon Valley and route 128. Cambridge, MA: Harvard University Press.

Schuetz, J. (2014). Do rail transit stations encourage neighborhood retail activity? Urban Studies, 52, 2699-2723. https://doi. org/10.1177/0042098014549128

Seo, K., Golub, A., \& Kuby, M. (2014). Combined impacts of highways and light rail transit on residential property values: A spatial hedonic price model for Phoenix, Arizona. Journal of Transport Geography, 41, 53-62. https://doi.org/10.1016/j. jtrangeo.2014.08.003

Song, Y., Lee, K., Anderson, W. P., \& Lakshmanan, T. R. (2012). Industrial agglomeration and transport accessibility in metropolitan Seoul. Journal of Geographical Systems, 14(3), 299-318. https://doi.org/10.1007/s10109-011-0150-z

Spigel, B. (2015). The relational organization of entrepreneurial ecosystems. Entrepreneurship: Theory and Practice, 41, 49-72. https://doi.org/10.1111/etap.12167

Stam, E. (2007). Why butterflies don't leave: Locational behavior of entrepreneurial firms. Economic Geography, 83(1), 27-50.

Storper, M., \& Scott, A. J. (2009). Rethinking human capital, creativity and urban growth. Journal of Economic Geography, 9(2), 147-167.

Storper, M., \& Venables, A. J. (2004). Buzz: Face-to-face contact and the urban economy. Journal of Economic Geography, 4(4), 351-370. https://doi.org/10.1093/jnlecg/lbh027

Van Soest, D. P., Gerking, S., \& Van Oort, F. G. (2006). Spatial impacts of agglomeration externalities. Journal of Regional Science, 46(5), 881-899. https://doi.org/10.1111/j.1467-9787.2006.00488.x 
Vessali, K. V. (1996). Land use impacts of rapid transit: A review of the empirical literature. Berkeley Planning Journal, 11(1), 72-105.

Voith, R. (1993). Changing capitalization of CBD-oriented transportation systems: Evidence from Philadelphia, $1970-1988$. Journal of Urban Economics, 33(3), 361-376. https://doi.org/10.1006/juec.1993.1021

Vojnovic, I., Lee, J., Kotval-K, Z., Podagrosi, A., Varnakovida, P., Ledoux, T., \& Messina, J. (2013). The burdens of place: A socio-economic and ethnic/racial exploration into urban form, accessibility and travel behavior in the Lansing Capital Region, Michigan. Journal of Urban Design, 18(1), 1-35. https://doi.org/10.1080/13574809.2012.683403

von Thünen, J. H. (1826). Der isolierte Staat in Beziehung auf Nationalalökonomie und Landwirtschaft. Reprinted 1966 by Gustav Fischer. English translation by Wartenberg, C.M.: von Thünen's isolated state. Oxford, UK: Pergamon Press.

Weinberger, R. R. (2001). Light rail proximity: Benefit or detriment in the case of Santa Clara County, California? Transportation Research Record, 1747, 104-111. https://doi.org/10.3141/1747-13

Weinstein, B., and Clower, T.L. (2003). DART light Rail's effect on taxable property valuations and transit-oriented development. University of North Texas. Retrieved from: http://www.valleymetro.org/images/uploads/general_publications/ 2003_DART_Study.pdf.

Wennekers, S., \& Thurik, R. (1999). Linking entrepreneurship and economic growth. Small Business Economics, 13(1), $27-55$. https://doi.org/10.1023/A:1008063200484

Wolfe, T. (1983). The tinkerings of Robert Noyce: How the sun rose on Silicon Valley. Esqiure, (December 1983), 346-347.

Yu, H., Junfeng, J., Houston, E., \& Peng, Z. R. (2018). Evaluating the relationship between rail transit and industrial agglomeration: An observation from the Dallas-Fort Worth region, TX. Journal of Transport Geography, 67(C), 33-52. https://doi.org/10.1016/j.jtrangeo.2018.01.008

\section{AUTHOR BIOGRAPHY}

Kevin Credit is a Lecturer in GIScience and the Assistant Director for Urban Informatics at the Center for Spatial Data Science at the University of Chicago. Kevin's work is broadly interested in better understanding how the spatial characteristics of cities-including the location of transportation systems and built environment patterns -influence sustainable economic development outcomes, such as new business creation.

How to cite this article: Credit K. Accessibility and agglomeration: A theoretical framework for understanding the connection between transportation modes, agglomeration benefits, and types of businesses. Geography Compass. 2019;13:e12425. https://doi.org/10.1111/gec3.12425 